\section{Mental Health Foundation Leaflets}

Members may be interested to learn that the Mental Health Foundation (in association with Barclays Bank) have produced a series of information leaflets on Schizophrenia and the Family, Seeing the Psychiatrist, Handling Stress and The Anxious Child which are available free of charge from the Mental

\section{Mental Health and Homelessness Report}

In 1989 the College's Public Education Committee arranged a Workshop with the Department of Health on the problems of the homeless mentally ill. At the October Meeting of Council, the Report of the
Health Foundation, 8 Hallam Street, London W1N 6DH.

These leaflets are being distributed to general practitioners and cover problems which are not dealt with by the College's Help is at Hand series of leaflets.

\title{
The use of psychotropic drugs in deportation procedures
}

The attention of the Special Committee on Unethical Psychiatric Practices has been drawn to the practice, in some countries, of using psychotropic drugs in deportation procedures.

The Committee will be grateful to receive reports from any members of the College who are aware of instances of such practices occurring at ports of entry in the UK.

Dr J. L. T. BIRLEY Chairman

Special Committee on Unethical Psychiatric Practices January 1991

\section{Mental IIIness Specific Grants}

Following a recent meeting of Council it was agreed that the Public Policy Committee should monitor local developments with regard to Mental Illness Specific Grants. A Working Party of the Committee has now been established to collect information at a local level on any problems encountered by services as well as examples of good practice.
The Working party would therefore be grateful if members could write to the Chairman of the Working Party, Dr Ann Gath, by Monday 18 March 1991 with any information as to what is happening to services at a local level.

\section{Where are the missing philosophers?}

The College computer has suffered short-term memory loss and deleted a number of Philosophy Group members.

Hopefully we have traced everyone, but if you have joined the Group and have not had Newsletter
No. 4, circulated in January, I would be very grateful if you would contact me or Jean Wales at the College. Many thanks.

Chairman, Philosophy Special Interest Group 